\title{
ŻYWOT ŚW. SAWY TEODOZJUSZA CHILANDARSKIEGO, JAKO ŹRÓDŁO DO DZIEJÓW STREZA, WłADCY PROSEKU
}

\author{
JAN M. WOLSKI
}

\begin{abstract}
Jan M. Wolski, „Żywot św. Sawy” Teodozjusza Chilandarskiego, jako źródto do dziejów Streza, wladcy Proseku ("Life of St. Sava" by Theodosius of Chilandar as a historical source on Strez, the ruler of Prosek).
\end{abstract}

Balcanica Posnaniensia. Acta et studia, XIX, Poznań 2012, Wydawnictwo Instytutu Historii UAM, pp. 51-70, ISBN 978-83-63-047-17-7, ISSN 0239-4278. Polish text with a summary in English.

Jan M. Wolski, Uniwersytet Łódzki, Instytut Historii, Katedra Historii Bizancjum, ul. Aleksandra Kamińskiego 27a, 90-219 Łódź, Polska - Poland.

\section{Wprowadzenie}

Koniec XII w. i początek XIII w. przyniosły znaczne przemiany w krajobrazie politycznym Bałkanów. Kryzys cesarstwa bizantyńskiego, powstanie Asenidów (1185 r.), a w końcu IV krucjata doprowadziły do znacznego rozdrobnienia politycznego w regionie $^{1}$. W pasmach górskich Rodopów oraz rejonach doliny Wardaru w latach 1186-

${ }^{1}$ Por. m. in.: D.M. Nicol, The Despotate of Epiros, Oxford 1957; G. Ostrogorski, Dzieje Bizancjum, tł. pod red. H. Evert-Kappesowej, Warszawa 1967, s. 322-353; Ch. M. Brand, Byzantium Confronts the West, 1180-1204, Cambridge Massachusetts 1968; G. Prinzing, Die Bedeutung Bulgariens und Serbiens in den Jahren 1204-1209 im Zusammenfasung mit der Entstehung und Entwicklung der byzantinischen Teilstaaten nach der Einnahme Konstantinopels infolge 4. Kreuzzuges, München 1972; А. ДанчеваВасилева, България и латинската империя (1204-1261), София 1981; В. Primov, The Third and Fourth Crusades and Bulgaria, „Études Historiques” 7, 1975, s. 43-68; R. Browning, Historia Bizancjum, tł. G. Żurek, Warszawa 1997, s. 166-175; M. Dąbrowska, Despotat Epiru w świetle najnowszych badań historycznych, „Balcanica Posnaniensia. Acta et Studia” 9/10, 1999, s. 77-99; Z. Pentek, Cesarstwo Łacińskie 1204-1261. Kolonialne państwo krzyżowców czy Neobizancjum?, Poznań 2004; J. Bonarek, Sytuacja Cesarstwa Bizantyńskiego w przededniu IV krucjaty, [w:] IV krucjata. Historia. Reperkusje. Konsekwencje, red. Z. J. Kijas, M. Salamon, Kraków 2005, s. 31-53; M. Angold, Czwarta krucjata, przeł. B. Spieralska, Warszawa 2006; P. Stephenson, The Balkan Borderlands (1018-1204), [w:] The Cambridge History of the Byzantine Empire, c. 500-1492, red. J. Shepard, Cambridge 2008, s. 686-690; M. Angold, After the Fourth Crusade: The Greek Rump States and the Recovery of Byzantium, [w:] tamże, s. 731-742; D. Jacoby, After the Fourth Crusade: The Latin Empire of Constantinople and the Frankish States, [w:] 
-1231 rządziło samodzielnie pięciu lokalnych władców, wygrywając przeciwko sobie zakusy Bizancjum, Bułgarii i Serbii, a później jeszcze Epiru i łacinników².

Jednym z tych, którzy wykorzystali zaistniałą sytuację, był Strez. Pochodził on z rodu Asenidów, dzierżącego wówczas władzę w Bułgarii. Po niespodziewanej śmierci cara Kałojana, zamordowanego pod murami Tesaloniki w 1207 r., Strez stał się jednym z pretendentów do tronu, o który ubiegali się również: jego brat Borił ${ }^{3}$ kuzyn Aleksy Sław oraz Jan Asen i Aleksander - nieletni jeszcze synowie Asena (zm. 1196), drugiego cara odnowionego państwa bułgarskiego. Ostatecznie władzę w Bułgarii przejął Borił, a jego konkurenci znaleźli się poza granicami kraju. Aleksy Sław zdołał utworzyć własne państwo w Rodopach i wkrótce sprzymierzył się z łacińskim cesarzem Konstantynopola Henrykiem ${ }^{4}$ Strez zaś udał się na dwór wielkiego żupana Raszki, Stefana Nemanicza (zwanego również Pierwszym Koronowanym), gdzie nie tylko znalazł schronienie, ale również uzyskał pomoc militarną. Dzięki wsparciu Serbów Strezowi udało się utworzyć niezależne państwo w Macedonii. Jego stolicą został Prosek - twierdza umiejscowiona na stromych i skalistych wzgórzach przełomu Wardaru. Kilka lat wcześniej była ona rezydencją innego lokalnego władcy Dobromira Chryza (w 1. 1197-1201)5. Prosek był bardzo korzystnie położony - na ważnym szlaku komunikacyjnym, a jednocześnie w trudnym do zdobycia miejscu. Militarne walory twierdzy barwnie opisywali pisarze bizantyńscy, po tym jak oparła się ona oblężeniu wojsk Aleksego III w 1198 r. ${ }^{6}$ Dzisiejsza nazwa znajdującej się tam osady - Demir Kapija - pochodzi od tureckiego wyrażenia ,żelazne wrota”.

tamże, s. 759-768; F. Van Tricht, The latin renovatio of Byzantium. The Empire of Constantionople (1204-1228), Leiden - Boston 2011; M.J. Leszka, Nicea - tymczasowa stolica Bizantyńczyków, „Piotrkowskie Zeszyty Historyczne" 12/2, 2012, s. 211-220.

2 Dogłębną analizę zjawiska władców lokalnych w świecie bizantyńskim przed upadkiem Konstantynopola w 1204 r. przedstawił Radiwoj Radić (Обласни господари у Византији крајем ХII и у првим деценијама ХІІІ века, „Зборник Радова Византолошког Института” 24/25, 1986, s. 159 -172). W polskiej nauce na tę problematykę zwrócił uwagę J. Bonarek (Separatyzm bizantyński $w$ dobie IV krucjaty a działalność Teodora Laskarysa, „Piotrkowskie Zeszyty Historyczne” 9, 2008, s. 27-41). Zob. też Г.Н. Николов, Самостоятелни и полусамостоятелни владения във възобновено Българско иарство (средата на XII - средата на XIII в.), София 2011.

${ }^{3}$ Stopień pokrewieństwa Streza i Boriła był niegdyś przedmiotem sporu. Wątpliwości, co do tego czy byli braćmi, sformułowała E. Sawczewa (Севастократор Стрез, „Годишник на Софийския Университет «Климент Охридски». Исторически факултет" 68, 1974, s. 70-72), jednak jej poglądy, niezbyt przekonujące, pozostały odosobnione. Źródłem kontrowersji jest fakt, że Streza i Boriła nazywa braćmi tylko jedno źródło: Stefan Nemanicz w Żywocie św. Symeona (wyd.: P. J. Šafařík, Život sv. Symeona od krále Štěpána. Z rukopisu XIII. století, [w:] Památky dřevního písemnictví Jihoslovanův, Praha 1873, s. 22; wyd.: В. Велинова; Житието на Стефан Неманя от Стефан Първовенчани (фототипично издание на преписа от средата на XV век); „Археографски прилози” 26/27, 2004/2005, s. 85), а роzostałe źródła (wymienione w dalszym ciągu pracy) pomijają ten fakt.

${ }^{4}$ Por. Г. Цанкова-Петкова, България при Асеневци, София 1978, s. 87-89; И. Божилов, Фамилията на Асеневци (1186-1460). Генеалогия и просопография, София 1994, s. 69-70, 77, 95-96, 98-99; tenże, В. Гюзелев, История на България в три тома, t. 1., История на средновековна България VII-XIV век, София 1999, s. 467-468; Г.Н. Николов, Самостоятелни владения, s. 99-101, 147-150.

${ }_{6}^{5}$ Р. Радић, Обласни господари, s. 193-205; Г.Н. Николов, Самостоятелни владения, s. 77-95.

${ }^{6}$ Tamże, s. 77-83. 
Krótka kariera polityczna Streza miała burzliwy przebieg. W ciagu swojego panowania dwukrotnie wyprawiał się on przeciwko cesarzowi konstantynopolitańskiemu Henrykowi, raz w sojuszu z władcą Epiru Michałem I Dukasem, a raz we współpracy z carem bułgarskim Boriłem. Trzecia, ostatnia wojna, przeciwko Stefanowi Nemaniczowi, uprzedniemu dobroczyńcy, zakończyła się śmiercią władcy Proseku nim doszło do starcia zbrojnego.

Zarys dziejów Streza znamy z dwóch grup źródeł narracyjnych: cyklu hagiograficznego poświęconego św. Symeonowi (Stefanowi Nemanii, ojcu Stefana Nemanicza) ${ }^{7}$ i św. Sawie (bratu Stefana Nemanicza) ${ }^{8}$ oraz z Listu cesarza Henryka do wszystkich jego przyjaciól $t^{9}$. Poza tym teksty z epoki jeszcze trzy razy wspominają imię Streza w jednym z listów Demetriusza Chomatenosa jest on określony jako władca Berroi ${ }^{10}$, w Synodyku Cerkwi bułgarskiej poświęcono mu wspomnienie ${ }^{11}$, a w projekcie umowy między cesarstwem łacińskim a Janem de Brienne wzmiankowane są ziemie, które niegdyś należały do Streza ${ }^{12}$.

Źródła serbskie zawierają opowieść o początku i końcu dziejów Streza jako samodzielnego władcy w Macedonii. Najstarsze z nich - Żywot św. Symeona - wyszło spod pióra ważnego uczestnika opisywanych wydarzeń, samego Stefana Nemanicza. Niewątpliwymi zaletami tego utworu, jako źródła historycznego, są naoczność świadectwa i niewielka odległość czasowa między jego powstaniem, a wydarzeniami, o których opowiada. Towarzyszą im jednak poważne wady związane z literackimi osobliwościami gatunku hagiograficznego (jak np. tendencje panegiryczne) oraz stronniczością autora ${ }^{13}$. Pozostałe dwa utwory - Żywot św. Sawy autorstwa Domentijana (z 1243 lub 1254 r.) $)^{14}$ i dzieło pod tym samym tytułem Teodozjusza Chilandarskiego

7 Stefan Nemanicz, Żywot św. Symeona, wyd.: P. J. Šafařík, wyd.: В. Велинова, s. 7-107. Niestety pozostałe wydania tekstu nie były mi dostępne.

${ }^{8}$ Teodozjusz Chilandarski, Żywot św. Sawy, wyd.: Ђ. Даничић, Живот светога Саве написао Доментијан, Биоград 1860; Domentijan, Żywot św. Sawy, wyd.: Ђ. Даничић, Живот светога Симеуна и светога Саве написао Доментијан, Биоград 1865.

${ }^{9}$ G. Prinzing, Der Brief Kaiser Heinrichs von Konstantinopel vom 13. Januar 1212. Überlieferungsgeschichte, Neuedition und Kommentar, „Byzantion” 43, 1973, s. 411-418. Dalej cytaty z tego źródła będę podawał pod skrótem: List Henryka.

${ }^{10}$ Demetrii Chomateni Ponemata Diaphora, 81. 5, wyd. G. Prinzing, Berolini et Novi Eboraci 2002, s. 276.

11 И. Божилов, А. Тотоманова, И. Билярски, Борилов синодик. Издание и превод, София 2010 , s. 161.

12 V. Gjuzelev, Documenta veneta historiam Bulgariae et bulgarorum illustrantia saeculis XII - XV, Serdicae 2001, s. 31-33. Wzmianka w żaden sposób nie poszerza naszej wiedzy o Strezie, zatem nie będę się do niej więcej odnosił. Radiwoj Radić (Обласни господари, s. 231) uważa ją za jeden z dowodów na to, że Strez pozostał do końca swego panowania władcą niezależnym.

${ }^{13}$ Utwór najprawdopodobniej powstał już w 1216 r. Рог. Д. Богдановић, Историја старе српске књижевности, Београд 1980, s. 153-154; J. Rapacka, Dawna literatura serbska i dawna literatura chorwacka, Warszawa 1993, s. 35-36, В. Велинова, Житието, s. 7-14, Р. Станкова, Сръбската книжнина през ХІІІ в. (контекст и текст), София 2007, s. 113-130.

14 Por. Д. Богдановић, Историја, s. 156-159; J. Rapacka, Dawna literatura, s. 36-37; Р. Станкова, Сръбската книжнина, s. 170-173. 
(z końca XIII lub początku XIV w.) ${ }^{15}$ - pozostają w genetycznym związku z Żywotem św. Symeona Stefana Nemanicza i starszymi żywotami św. Sawy ${ }^{16}$. Domentijan i Teodozjusz musieli dysponować jeszcze jakimiś dodatkowymi źródłami informacji, gdyż dopełniają swoje teksty o szczegóły nieznane ich poprzednikom. Najobszerniej dzieje Streza zrelacjonował Teodozjusz Chilandarski, dlatego też postanowiłem zaprezentować tutaj tłumaczenie fragmentu właśnie jego dzieła.

List cesarza Henryka do wszystkich jego przyjaciół datowany na 13 I 1212 lub 1213 r. ${ }^{17}$ zawiera opis kilku kampanii wojennych prowadzonych przez jego autora. Cesarz łaciński donosi papieżowi Innocentemu III i ,,wszystkim swoim przyjaciołom, do których ten list dotrze” o triumfach odniesionych nad „czterema głównymi przeciwnikami”: Michałem I Dukasem, Teodorem Laskarysem, Boriłem i Strezem. List kończy się apelem o pomoc - ,do pełnego zwycięstwa [...] nie brakuje nam niczego innego, jak tylko wojsk łacińskich" ${ }^{18}$. Mimo że niektóre ustępy tego źródła wydają się czczymi przechwałkami ${ }^{19}$, to jednak główny tok opowieści jest powszechnie uważany za wiarygodny ${ }^{20}$.

W dalszej części artykułu chciałbym poświęcić więcej uwagi kilku wybranym problemom związanym z dziejami Streza. Należą do nich: chronologia zdarzeń z jego życia, relacje z państwami sąsiednimi, zasięg terytorialny jego państwa oraz okoliczności śmierci.

Problemy z ustaleniem chronologii poczynań Streza wynikają ze specyfiki źródeł. Literatura hagiograficzna rzadko kiedy zawiera daty, a wykorzystane tu teksty nie są w tym aspekcie wyjątkiem. Sekwencję zdarzeń znaną z żywotów św. Symeona i św. Sawy: ucieczka Streza z Bułgarii, pobyt na dworze Stefana Nemanicza, zajęcie Proseku z pomocą serbską możemy datować jedynie w przybliżeniu. Należy ją umieścić między październikiem 1207 r., a jesienią - wiosną 1210-1211 lub 1211-

15 Por. Д. Богдановић, Историја, s. 171-172; J. Rapacka, Dawna literatura, s. 37; Р. Станкова, Сръбската книжнина, s. 178-180.

16 Niewiele jest w tych utworach zapożyczeń dosłownych, autorzy wzorują się na sobie co do sposobu prezentacji wydarzeń, doboru cytatów biblijnych, czy uzasadnień czynów ich bohaterów. Por. literatura wskazana w przyp. 14 i 15.

17 Dysponujemy trzema kopiami tego listu, które wskazują na różne daty jego powstania. Do niedawna uczeni zgodnie uznawali kopię z datą 1212 r. za najbardziej miarodajną. Ostatnio Filip Van Tricht (La politique étrangère de l'empire de Constantinople de 1210 à 1216 (1 re partie), „Le Moyen Age” 117/2, 2001, s. 221-227, tam też odwołania do starszej literatury) przywołał argumenty przemawiające na korzyść innego rękopisu, z datą 1213 r. (trzecia kopia jest bez daty). Ustalenia belgijskiego badacza nie są rozstrzygające, zatem będę podawać czas powstania listu, jak i wszystkie daty wydarzeń opisanych w nim, w dwóch wariantach różniących się o rok.

18 List Henryka, s. 411, 418.

19 Np.: ,gdyby ważniejsze sprawy nie przyzywały nas nieustannie, nie pozostałaby w ich [tj. Michała I Dukasa i Streza - przyp. J. M. W.] rękach ani piędź ziemi [dosł. ani jeden domek - przyp. J. M. W.]" (List Henryka, s. 412), przesadą wydaje się również podkreślana przez Henryka znaczna liczba zabitych w bitwie przeciwników przy zupełnym braku strat we własnych szeregach (List Henryka, s. 417).

${ }^{20}$ Badacze obszernie wykorzystują omawiany list rekonstruując dzieje Cesarstwa Łacińskiego: G. Prinzing, Der Brief Kaiser Heinrichs, s. 418-431; Z. Pentek, Cesarstwo Eacińskie, s. 130-137; F. Van Tricht, La politique étrangère, s. 225; tenże, The latin renovatio, s. 184, 186, i in. 
-1212 r. Terminus post quem (tj. data śmierci Kałojana podana w Kronice Alberyka de Trois-Fontaines ${ }^{21}$ ), zdroworozsądkowo uogólniony do końcówki 1207 czy też początku 1208 r., bywa przyjmowany jako data ucieczki Streza z Bułgariii ${ }^{22}$. Określenie czasu objęcia władzy nad Prosekiem jest o wiele bardziej kontrowersyjne, gdyż nie wiemy, jak długo Strez zabawił na dworze wielkożupańskim ${ }^{23}$. Możemy jedynie określić terminus ante quem, który wyznacza pierwsze wystąpienie Streza, jako samodzielnego gracza w polityce międzynarodowej. Wydarzeniem tym był wspólny atak Streza i Michała I Dukasa na włości łacinników odnotowany w przywoływanym wyżej liście cesarza Henryka (tj. jesień - wiosna 1210-1211 lub 1211-1212 r. $)^{24}$

Jeszcze przed przystapieniem do wspomnianej wojny Strez złożył cesarzowi Henrykowi przysięgę wierności (fidelitatis sacramentum). Podjęte wbrew niej walki skończyły się zarówno dla Streza jak i Michała I porażką. Władca Konstantynopola przechwalał się w swym liście, że zajął większą część spośród najlepszych ziem obu przeciwników, a byłby zajął wszystkie, gdyby go nie zawróciły ważniejsze sprawy ${ }^{25}$. Wiosną 1211 lub 1212 r. władca Proseku spróbował wziąć odwet, znów jednak poniósł porażkę. W bitwie na Równinie Pelagońskiej (w okolicach dzisiejszej Bitoli), która rozstrzygnęła wojnę, Strez dysponował posiłkami od Boriła, a wojska łacińskie wsparł Michał I Dukas²6.

${ }^{21}$ Dokładnie 8 X 1207 r., za: Z. Pentek, Cesarstwo Lacińskie, s. 119.

22 Por. П. Мутафчиев, Владетелите на Просек. Страници из историята на българите в края на XII и началото на ХIII век, [w:] tenże, Изток и запад в европейското Средновековие, София 1993, s. 88; Г.Н. Николов, Самостоятелни владения, s. 99.

${ }^{23}$ Georgi N. Nikołow (Самостоятелни владения, s. 104) twierdzi, że Strez zdobył Prosek latem 1208 r. Petyr Mutafcziew (Владетелите на Просек, s. 88) wyznacza terminus ante quem tego wydarzenia na jesień $1208 \mathrm{r}$. Za bardzo prawdopodobne uznał on, że Stefan i Strez wykorzystali walki Boriła i Henryka (w 1208 r.), aby napaść na Macedonię. Por. Е. Савчева, Севастократор Стрез, s. 76; Р. Радић, Обласни господари, s. 226.

${ }^{24}$ List Henryka, s. 413-414. Por. G. Prinzing, Der Brief Kaiser Heinrichs, s. 423; F. Van Tricht, La politique étrangère, s. 234. Günter Prinzing zwraca uwagę, że nie możemy byś pewni czy Michał I Dukas istotnie działał w sojuszu ze Strezem. Georgi N. Nikołow (Самостоятелни владения, s. 107) bez wystarczającego uzasadnienia umiejscawia wspomniane walki w okresie grudzień 1208 - jesień 1209. Iwan Bożiłow (Фамилията на Асеневци, s. 70) odnosi pierwsze kroki Streza na arenie międzynarodowej na 1209 r. Niesłusznie wiąże on oblężenie Serresu, o którym wspomina Henri de Valenciennes (Histoire de l'empereur Henri de Constantinople, 618-619, wyd. J. Longnon, Paris 1948, s. 85), z postacią Streza. Z kontekstu cytowanego ustępu w Historii de Valensciennes'a jasno wynika, że Henryk obległ zbuntowanych przeciwko niemu Lombardczyków, a nie Streza. Zupełnie nieuzasadniona jest również hipoteza oparta na interpretacji innego fragmentu przekazu de Valenciennes'a (Histoire de l'empereur Henri, 688-694, s. 118-121), zakładająca udział Streza w mniemanej kampanii Michała I Dukasa przeciwko cesarzowi Henrykowi w 1209 r. (П. Мутафчиев, Владетелите на Просек, s. 95; И. Божилов, Фамилията на Асеневии, s. 99).

${ }^{25}$ List Henryka, s. 411-412.

${ }^{26}$ List Henryka, s. 413-414, kampanię należy datować na okres marzec/kwiecień - czerwiec 1211 lub 1212 r. Jej opis poprzedza wzmianka o Wielkanocy (tj. 3 IV dla 1211 r., a 25 III dla 1212 r.) spędzonej w Rusjonie, a sama bitwa miała miejsce w trakcie pobytu Henryka w Konstantynopolu, który trwał co najmniej do lipca 1211/1212 r. 
Cesarz Henryk narzekał na przewrotność władcy Macedonii - miał on trzykrotnie składać przysięgę wierności i tyle samo razy ją łamać27. W treści listu znajdujemy tylko dwie takie sytuacje. Można by z tego wnioskować, że przed czasami opisanymi przez Henryka, Strez jeszcze raz przyrzekł przyjaźń, a następnie wystąpił przeciwko władcy Konstantynopola. Nie wydaje się jednak, abyśmy mogli przywiązywać wagę do podanej liczby - autor źródła miał skłonność do przesady. Należy tutaj podkreślić, że mimo składanych przysiag Strez nie został władcą faktycznie zależnym od cesarstwa łacińskiego, ani nie stał się jego sojusznikiem.

W przedstawionych powyżej wydarzeniach zwraca uwagę fakt, że Borił w 1211 lub 1212 r. udzielił pomocy Strezowi. W początkowym okresie jego rządów w Macedonii to Serbowie byli jego najbliższymi sojusznikami i być może rościli sobie pretensje do zwierzchnictwa nad nim. Strez utworzył przecież swoje państwo z pomocą wielkiego żupana Stefana Nemanicza. Uzyskał od niego nie tylko wsparcie militarne, ale również swoistą rekomendację u możnych, rządzących południową częścią Macedonii Wardarskiej. Mimo że w $1207 \mathrm{r}$. Strez nie był postacią anonimową̨ $a^{28}$, to wykorzystał on wstawiennictwo władcy Serbii i deklarację dalszej współpracy dla podniesienia własnego autorytetu. Być może bez tego nie byłby w stanie przekonać lokalnych elit do uznania w sobie władcy. Stefan Nemanicz przedstawia swoje ówczesne stosunki ze Strezem w następujący sposób: ,przekazałem mu połowę carstwa bułgarskiego i umocniłem go w mieście zwanym Prosek [...] podtrzymywałem jego władzę i chroniłem go przed wszystkimi, którzy wyrządzali mu krzywdę"29. Opieka, jaką obdarzył Streza, sugeruje niesymetrię ich relacji. Wizję równorzędności między władcami przedstawia Teodozjusz: „,[Stefan] umocnił go [tj. Streza] i uczynił władca, zaszczycił będąc jego towarzyszem i bratem. Obaj obiecali przychodzić sobie z wszelką pomocą" ${ }^{30}$. Nawet, jeśli ich wzajemne stosunki nie przekształciły się w formalnie określoną zależność, to i tak nie mogły być w pełni partnerskie, zważywszy na różnicę w potencjale militarnym między nimi. To raczej Strez, kształtując swoją politykę, musiał się liczyć z planami Stefana, a nie na odwrót ${ }^{31}$. Poza zajęciem Proseku źródła nie odnotowały żadnej ich wspólnej akcji. Hagiografia serbska za rozpad współpracy obwiniała Streza ${ }^{32}$. Nawet, jeśli wojna przeciwko dawnym opiekunom wybuchła z jego inicjatywy, to ich więź osłabła być może już wcześniej z winy władcy Serbii. Po klęsce w walkach z cesarzem Henrykiem w 1210-1211 lub 1211-1212 r. nadwardarski władca potrzebował wsparcia militarnego i otrzymał je nie od Stefana Nemanicza,

27 Podobny zarzut był wysuwany również przeciwko Michałowi I Dukasowi, List Henryka, s. 412.

${ }^{28} \mathrm{Z}$ dzieła Teodozjusza Chilandarskiego (Żywot św. Sawy, s. 104) dowiadujemy się o Strezie, że „mieszkańcy Zagory znali go [...]” oraz że „słynął ze swojego wyjątkowego męstwa”.

${ }^{29}$ Stefan Nemanicz, Żywot św. Symeona, wyd.: P. J. Šafařík, s. 22-23, wyd:. В. Велинова, s. 86.

30 Teodozjusz Chilandarski, Żywot św. Sawy, s. 105.

31 Ani Danczewa-Wasilewa (България и латинската, s. 88-89) twierdzi, że Stefan Nemanicz sprawował zwierzchność senioralną („,юзеренитет”) nad Strezem, choć jak sama zauważa nie ma wzmianek źródłowych bezpośrednio potwierdzających tę opinię.

32 Stefan Nemanicz, Żywot św. Symeona, wyd.: P. J. Šafař́k, s. 23, wyd.: В. Велинова, s. 86-87; Domentijan, Żywot św. Sawy, s. 206; Teodozjusz Chilandarski, Żywot św. Sawy, s. 107. 
ale od Boriła. Możemy te zdarzenia interpretować jako niedopełnienie zobowiązania udzielania pomocy przez wielkiego żupana, które poskutkowało sprzymierzeniem się Streza z bułgarskim carem ${ }^{33}$.

Źródła podają skąpe lub mało wiarygodne informacje o miejscowościach i twierdzach znajdujących się pod władzą Streza ${ }^{34}$. Serbskie utwory hagiograficzne zgodnie potwierdzają, że siedzibą bułgarskiego wielmoży był Prosek ${ }^{35}$. Stefan Nemanicz napisał z przesada, że oddał w ręce Streza ,połowę carstwa bułgarskiego"36. Dokładniejsze wiadomości przekazał Teodozjusz Chilandarski. Według niego władzy Streza poddali się Zagorzanie (tj. Bułgarzy), którzy władali Ochrydą ${ }^{37}$ i okolicami Tesaloniki ${ }^{38}$. Druga z tych lokalizacji wymaga komentarza. Według wszelkiego prawdopodobieństwa obszary w bezpośredniej bliskości miasta pozostały w rękach rycerzy lombardzkich. Z miejsc położonych niedaleko Tesaloniki Strez władał Berroią (dz. Veroia) ${ }^{39}$ oddaloną od niej o ok. $60 \mathrm{~km}$ na południowy zachód. Na tym wyczerpuje się nasza wiedza o posiadłościach bułgarskiego wielmoży. Zupełnie logiczne byłoby przypuszczenie, że władał on nie tylko trzema enklawami, ale również ziemiami położonymi

${ }^{33}$ Większość autorów przesuwa sprzymierzenie się Streza z Boriłem na 1208 lub 1209 r. Jest to wywołane nieuzasadnionym źródłowo przekonaniem o nieszczerych intencjach Streza i Stefana Nemanicza przy zawieraniu porozumienia o wzajemnej pomocy (П. Мутафчиев, Владетелите на Просек, s. 90; Е. Савчева, Севастократор Стрез, s. 78, 81; Р. Радић, Обласни господари, s. 227). Nie do przyjęcia jest też propozycja Wasila Złatarskiego, który próbuje uzasadnić podobną datację na podstawie fragmetnu Historii de Valenciennes'a (Histoire de l'empereur Henri, 689, s. 118-119). Opisany tam pochód Boriła przeciwko łacinnikom z 1208 r. uznaje on za akcję w rzeczywistości skierowaną przeciwko Strezowi, która finalnie miała doprowadzić do przymierza między oboma braćmi (В. Златарски, История на българската държава през средните векове, t. 3, Второ българско иарство. България при Асеневци (1187-1280), София 1940, s. 284-285). Wielu historyków uznało jego interpretację za prawdopodobną (И. Божилов, Фамилията на Асеневии, s. 99; Е. Савчева, Севастократор Стрез, s. 79; Р. Радић, Обласни господари, s. 227-228). Georgi N. Nikołow (Самостоятелни владения, s. 108) przyjmuje rok 1210 lub 1211 za datę pojednania Streza z Boriłem, zaś Günter Prinzing - początek roku 1211 (Die Bedeutung, s. 105-106). Naturalnie nie biorą oni pod uwagę 1212 r., gdyż uznają styczeń 1212 r. za datę napisania Listu cesarza Henryka do wszystkich jego przyjaciót.

${ }^{34}$ Nieudaną próbę poszerzenia naszej wiedzy na ten temat podjęli Franio Bariszić i Bożidar Ferjanczić (Вести Димитрија Хоматиана о «власти Драгувита», „Зборник Радова Византолошког Института” 20, 1981, s. 41-58. Będące podstawą ich wywodów utożsamienie „władzy Draguwitów” ze Strezem jest nieprzekonujące. Por. И. Билярски, Институциите на средновековна България. Второ българско иарство (XII - XIV век), София 1998, s. 103 (podobnie kwestionuje on postulowane przez przywołanych wyżej autorów rozróżnienie między „Draguwitami” i „Bułgarami”, mimo że przyjmuje ich wnioski).

${ }^{35}$ Stefan Nemanicz, Żywot św. Symeona, wyd.: J. P. Šafař́ík, s. 22, wyd.: В. Велинова, s. 86; Teodozjusz Chilandarski, Żywot św. Sawy, s. 105.

${ }^{36}$ Stefan Nemanicz, Żywot św. Symeona, wyd.: J. P. Šafařík, s. 22, wyd.: В. Велинова, s. 86.

$37 \mathrm{O}$ ówczesnym znaczeniu tego ośrodka władzy kościelnej por. G. Prinzing, A quasi patriarch in the state of Epiros: the autocephalous archbishop of ,Boulgaria” (Ohrid) Demetrios Chomatenos, „Зборник Радова Византолошког Института” 41, 2004, s. 165-182, J. Dudek, Blaski i cienie ,epirockiego separatyzmu” kościelnego w latach 1204-1230, „Piotrkowskie Zeszyty Historyczne” 12/2, 2012, s. 197-209, tam też dalsza literatura.

38 Teodozjusz Chilandarski, Żywot św. Sawy, s. 105.

${ }^{39}$ Demetrii Chomateni Ponemata Diaphora, 81. 5, s. 276. Nie wiadomo niestety kiedy Strez opanował Berroię. 
między Prosekiem, Berroią i Ochrydą. W skład jego włości wchodziłyby zatem Woden (dz. Edessa), Moglena (w okolicach dz. Aridai), Ostrowo (dz. Arnissa), Pelagonia (dz. Bitola), ewentualnie Kastoria i Prespa (położone na południe od Pelagonii), a być może jeszcze Prilep oraz położona na wschodzie Strumica. Dwa ostatnie miasta leżą w pobliżu Proseku (Strumica) i Bitoli (Prilep), i włączam je do włości Strezowych przez analogię do kształtu państwa Dobromira $\mathrm{Chryza}^{40}$, co oczywiście nie jest zabiegiem dającym pewność. Według Teodozjusza Chilandarskiego Strez po zawładnięciu Prosekiem, Ochrydą i okolicami Tessaloniki „objął w posiadanie kolejne miasta i wzrosła liczba jego ludzi"41.

Zagadnieniem otwartym pozostaje kwestia przynależności państwowej Macedonii północnej, a więc Welesu, Górnego i Dolnego Połogu oraz okolic Skopje. Choć źródła milczą o ich ówczesnych dziejach, większość badaczy przyjmuje, że tereny te należały do państwa Streza ${ }^{42}$.

Należy przypomnieć w tym kontekście cytowaną już deklarację cesarza Henryka, że w początkach 1211 lub 1212 r. zajął on najlepsze ziemie Michała I Dukasa i Streza, oraz fakt, że kilka miesięcy później bułgarski wielmoża poniósł kolejną klęskę z rąk łacinników ${ }^{43}$. Jakie terytoria mógł wówczas utracić Strez? Najprawdopodobniejsza byłaby hipoteza, że były to twierdze położone na południowo-zachodnich rubieżach jego państwa, czyli np. Berroia oraz Woden, Moglena i Ostrowo. Milczenie źródeł unieważnia te spekulacje.

Ostatnie epizody z życia Streza znamy z serbskich utworów hagiograficznych. Według nich miał on stracić życie za sprawą interwencji boskiej w trakcie działań wojennych, które prowadził przeciwko Serbii. Motywy, które doprowadziły do wojny nie są naświetlone przez źródła (jeśli pominiemy podszepty Złego ${ }^{44}$ ). Konflikt zbrojny możemy stosunkowo pewnie datować na rok $1214^{45}$. Opowieść o śmierci Streza w Żywocie św. Symeona jest umieszczona między ustępem o wojnie z Henrykiem i Boriłem, a fragmentem dotyczącym ataku Michała I Dukasa na Serbię. Oba wy-

40 O posiadłościach Dobromira Chryza: Г.Н. Николов, Самостоятелни владения, s. 87-91, 95. Odnośnie do Strumicy podobnie wypowiada się Radiwoj Radić (Обласни господари, s. 230).

41 Teodozjusz Chilandarski, Żywot św. Sawy, s. 105.

42 K. Jireček, Geschichte der Serben, t. 1, Bis 1371, Gotha 1911, s. 293; Ф. Баришић, Б. Ферјанчић, Вести Димитрија Хоматиана, s. 54, 55, J. Dudek, Polog i jego rola na bizantyńskim pograniczu w XI - XIII w., „Acta Universitatis Wratislaviensis. Historia” 152 (2306), 2001, s. 151, Г.Н. Николов, Самостоятелни владения, s. 119-120.

43 List Henryka, s. 412.

44 Stefan Nemanicz, Żywot św. Symeona, wyd.: J. P. Šafař́́k, s. 23, wyd.: В. Велинова, s. 86; Domentijan, Żywot św. Sawy, s. 206.

45 П. Мутафчиев, Владетелите на Просек, s. 104-105; Е. Савчева, Севастократор Стрез, s. 86; Р. Радић, Обласни господари, s. 234; F. Van Tricht, The latin renovatio, s. 397-398. Votum separatum zgłosił Günter Prinzing. Według niego Strez umarł już w 1211 r. (G. Prinzing, Die Bedeutung, s. 106). Podobne poglądy wyraża Georgi N. Nikołow: według niego Strez zmarł przed 1212 r. Za ważny argument przemawiający na korzyść swojej hipotezy bułgarski uczony uważa to, że po klęsce Streza na Równinie Pelagońskiej nie jest on więcej wspominany w Liście cesarza Henryka do wszystkich jego przyjaciót (Г.Н. Николов, Самостоятелни владения, s. 111). Zdaje się on nie zauważać, że analogiczny argument można by odnieść do Michała I Dukasa, który jednakże z pewnością przeżył jeszcze kilka lat. 
darzenia są zazwyczaj datowane na ten sam rok 1214. Pierwsze miało miejsce najwcześniej w $1213 \mathrm{r}^{46}$, a drugie przed lutym 1215 r., kiedy to już z pewnością nie żył Michał I Dukas ${ }^{47}$. Nierozwiązywalne pozostaje zagadnienie czy trzy strony walczące przeciwko Serbii w 1214 r. działały w porozumieniu. Udział władcy Epiru w ewentualnej koalicji jest najbardziej wątpliwy ${ }^{48}$. Strez z Boriłem według wszelkiego prawdopodobieństwa pozostawali wówczas w przyjaznych stosunkach, więc być może uzgodnili ze sobą działania. Warto zwrócić uwagę na pewien ustęp z Żywotu św. Sawy Teodozjusza Chilandarskiego, który może być w tym kontekście różnorodnie interpretowany ${ }^{49}$. Strez, planując wyprawić się przeciwko Stefanowi, „pojednał się z Grekami i połączył ze swoimi Gotami - zebrał z obu [narodów] niezliczone mnóstwo ludzi”"50. Być może wymienieni w tekście Grecy i Goci (tj. Bułgarzy) reprezentują Epir ${ }^{51}$ i carstwo bułgarskie, ale równie uzasadnione jest stanowisko, że mowa tu o poddanych władcy Proseku obu narodowości. Wskazywał by na to zaimek „,swoi” odnoszący się do Gotów/Bułgarów i druga część cytatu kojarząca się raczej z zaciaggiem niż wzywaniem posiłków z obcych państw.

Okoliczności śmierci Streza wymykają się jednoznacznej interpretacji. Dla hagiografów serbskich była ona cudem dokonanym przez świętego i tylko dlatego opowieść o niej znalazła miejsce w ich utworach. Potwierdzona w nich sprawcza rola Sawy w zabójstwie ${ }^{52}$ jest często akceptowana przez historyków ${ }^{53}$. W ich interpretacjach miejsce cudu wywołanego modlitwą zajmuje spisek. Możemy jednak, pozosta-

46 Wtedy najprawdopodobniej zawiązny został sojusz między Henrykiem a Boriłem potwierdzony małżeństwem jego córki lub siostry z cesarzem konstantynopolitańskim, po którym nastąpił również ślub Boriła z córką Jolanty i Piotra de Courtenay. Data nie jest pewna, ale dość powszechnie przyjmowana. Г. Цанкова-Петкова, Българо-гръцки и българо-латински отношения при Калоян и Борил, „Извеситя на Института за История” 21, 1970, s. 165; И. Божилов, Фамилията на Асеневци, s. 93-94; tenże, В. Гюзелев, История на България, s. 473; F. Van Tricht podaje koniec 1213 - początek 1214 (The latin renovatio, s. 392; w swojej wcześniejszej pracy przyjmuje 1213 r., La politique étrangère, s. 237-238, przyp. 84). Z. Pentek: 5 VIII 1213 - 4 VIII 1214 r. (Cesarstwo Łacińskie, s. 142).

47 Data śmierci Michała I: D.M. Nicol, The Despotate, s. 42; Б. Ферјанчић, Србија и византијски свет у првој половини ХІІІ века, „Зборник Радова Византолошког Института” 27/28, 1989, s. 110.

48 Por. Ф. Баришић, Б. Ферјанчић, Вести Димитрија Хоматиана, s. 55-56; Р. Радић, Обласни господари, s. 233-234. Udział Michała I Dukasa w hipotetycznej koalicji zakłada m. in. Elena Sawczewa (Севастократор Стрез, s. 86).

49 Por. П. Мутафчиев, Владетелите на Просек, s. 102-103.

50 Teodozjusz Chilandarski, Żywot św. Sawy, s. 107.

51 P. Mutafcziew (Владетелите на Просек, s. 102-103) interpretuje wspomnianych tu Greków jako łacinników. Uzasadnia to pomieszaniem obu etnonimów w Żywocie św. Symeona autorstwa Stefana Nemanicza.

52 Domentijan, Żywot św. Sawy, s. 208-209; Teodozjusz Chilandarski, Żywot św. Sawy, s. 111-112.

53 Е. Савчева, Севастократор Стрез, s. 85; Г.Н. Николов, Самостоятелни владения, s. 113. Georgi N. Nikołow twierdzi, że śmierć Streza nastąpiła w Proseku. Jest to sprzeczne z przekazem Żywotu św. Sawy Teodozjusza Chilandarskiego, według którego Strez wyruszył już wówczas przeciwko Stefanowi, a cała rzecz dzieje się w obozie (Sawa jest ugoszczony w namiocie; Teodozjusz Chilandarski, Żywot św. Sawy, s. 107, 111). Utwory Domentijana i Stefana Nemanicza nie pozwalająjednoznacznie rozsądzić tego zagadnienia, być może Teodozjusz dzięki umieszczeniu tych wydarzeń na ziemiach Stefana buduje napięcie mające powiększyć zasługi św. Sawy niezależnie od rzeczywistego przebiegu zdarzeń. 
jąc bliżsi literze żywotów, nie doszukiwać się naturalnego (możliwego do ukazania bez odwoływania się do mocy nadprzyrodzonych) związku Sawy ze śmiercią Streza, a przypisać jej spowodowanie żołnierzom niezadowolonym z postępowania ich wodza $^{54}$ lub przypadkowi (zawałowi serca, etc.).

Nie znamy losów nadwardarskiego państwa po śmierci Streza. Część ziem dostała się najprawdopodobniej w ręce Boriła. Według większości badaczy Prosekiem zawładnęli łacinnicy ${ }^{55}$. Zagadką pozostaje rola Serbów w wydarzeniach z 1214 r., wydaje się, że nie odnieśli oni żadnej korzyści terytorialnej ze „Zwycięstwa” nad Strezem. Być może zagrożenie na dwóch frontach (ze strony Epiru i połączonych sił łacińskobułgarskich) nie pozwoliło im zaangażować się w podbój Macedonii.

Pamięć o Strezie przetrwała w podaniach ludowych ${ }^{56}$ oraz Synodyku cara Borita ${ }^{57}$. Wspomniane legendy nie są wiarygodne jako źródła historyczne, dlatego zwrócę uwagę tylko na przywołany dokument Cerkwi bułgarskiej. Imię władcy Proseku jest w nim zapisane wraz z tytułem sebastokratora. Okoliczności, w jakich otrzymał on tę godność, są nieznane ${ }^{58}$. W cesarstwie bizantyńskim obdarzano nią osoby bliskie cesarzowi, spokrewnione lub spowinowacone z nim. Do połowy XIII w. sebastokrator był drugą co do godności osobą w państwie, później ustapił miejsca despocie. W początkach XIII w. z tym tytułem nie wiązały się żadne określone funkcje, jedynie wysoki prestiz $\dot{z}^{59}$.

54 П. Мутафчиев, Владетелите на Просек, s. 103-104; Р. Радић, Обласни господари, s. 234. Pierwszy z cytowanych autorów dopuszcza udział Sawy w spisku przeciwko Strezowi.

55 K. Jireček, Geschichte der Serben, s. 293; П. Мутафчиев, Владетелите на Просек, s. 105-107; Е. Савчева, Севастократор Стрез, s. 86; К. Аџиевски, Пелагонија во средниот век (од доаѓањето на Словените до паѓььето под турска власт), Скопје 1994, s. 132-133; F. Van Tricht, The latin renovatio, s. 379. Ani Danczewa-Wasilewa (България и латинската, s. 97) twierdzi z kolei, że Borił przyłączył do swojego państwa wszystkie ziemie podległe Strezowi.

56 И. Снегаров, История на охридската архиепископия, t. 1, От основаването и до завладяването на Балканския полуостров от туричите, София 1995, s. 254; Г.Н. Николов, Самостоятелни владения, s. 116-117.

${ }^{57}$ И. Божилов, А. Тотоманова, И. Билярски, Борилов синодик, s. 161.

58 Pierwsza redakcja tego dokumentu powstała najpóźniej w lutym 1211 r., co jednak nie znaczy, że już wtedy znalazła się tam wzmianka o Strezie. Najstarsza zachowana kopia Synodyka cara Boriła pochodzi z XIV w. Iwan Bożiłow (И. Божилов, А. Тотоманова, И. Билярски, Борилов синодик, s. 41), autor komentarza historycznego do cytowanego wydania, bardzo ostrożnie wypowiedział się co do czasu wpisania imienia Streza do Synodyku, określił jedynie terminus ante quem na 1277 r.

${ }^{59}$ И. Билярски, Институциите, s. 85-99. Wielu badaczy podnosiło problem formalnej zależności Streza od Boriła w związku z otrzymaniem od niego tytułu sebastokratora. Ciekawe uwagi odnośnie tego stanowiska podaje R. Radić (Обласни господари, s. 229, 231). Szeroko dyskutowana była kwestia ewentualnego nadania Strezowi tytułu sebastokratora przez Kałojana, dyskusję krytycznie relacjonuje Iwan Biliarski (Институциuте, s. 99-100). Petyr Mutafcziew twierdził nawet, że Strez nosił wspomniany tytuł jedynie za panowania Kałojana (Владетелите на Просек, s. 73-74, por. Г.Н. Николов, Самостоятелни владения, s. 100). Jednak fakt, że imię Streza zostało zapisane w Synodyku cara Boriła razem z tytułem sugeruje, że władca Proseku nosił go w ostatnich latach swojego życia. Jako że nie wiemy nic pewnego o roli Streza w życiu politycznym Bułgarii przed 1207 r., mniej obarczone ryzykiem błędu wydaje mi się twierdzenie, że otrzymał on wspomniany tytuł po tej dacie, czyli w latach panowania Boriła (najprawdopodobniej po 1211-1212 r.) 
Na zakończenie, chciałbym zwrócić uwagę na pominięty do tej pory wątek, który jest bardzo ważny dla zagadnienia wiarygodności opowieści $O$ nagłej śmierci Streza. Analizowane źródło jest tendencyjne, interesująca nas postać jest przedstawiona w nim w bardzo niekorzystnym świetle. Mówi się o nim jako o zatwardziałym głupcu, niewdzięczniku i osobie okrutnej. Teodozjusz Chilandarski oparł się w tym fragmencie na świadectwie Stefana Nemanicza i Domentijana, wskazujących na szatańskie inspiracje w zachowaniu Streza ${ }^{60}$. Dopełnił ich retoryczne wywody konkretnymi faktami (mam tu na myśli przede wszystkim opis libacji, podczas których bułgarski wielmoża skazywał ludzi na wymyślną śmierć). Być może w ciągu tych kilkadziesięciu lat, które dzielą powstanie dzieł Domentijana i Teodozjusza, narodziła się czarna legenda władcy Proseku. Nigdy się już nie dowiemy czy u jej podstaw leżały plotki, czy też prawdziwe zdarzenia. Nie bez znaczenia jest też fakt, że celem napisania utworu Teodozjusza Chilandarskiego nie była obiektywna renarracja faktów, tylko pochwała świętego Sawy. Autor wykorzystuje okrucieństwo Streza do usprawiedliwienia „zabójstwa" dokonanego przez swojego bohatera ${ }^{61}$, co mogło być przyczyną ubarwienia przez niego tej opowieści. Panegiryczne i parenetyczne motywy powstawania utworów hagiograficznych sprawiają, że są one źródłami trudnymi do interpretacji dla współczesnych historyków. Pamięć o bestialskich postępkach Streza jeszcze w końcówce XIX w. była żywa wśród mieszkańców Macedonii ${ }^{62}$.

Podstawą zamieszczonego niżej przekładu jest przestarzałe już, ale ciągle jedyne wydanie szesnastowiecznego rękopisu Żywotu św. Sawy Dź. Daniczicia z 1860 r. ${ }^{63}$ Obecnie znamy ponad 10 kopii tego tekstu, z których najstarsze pochodzą z XIV w. ${ }^{64}$ Na język polski, jak dotychczas, przetłumaczony został jedynie krótki fragment $\dot{Z} y$ wotu pióra Teodozjusza Chilandarskiego. Jego autorem jest Aleksander Naumow ${ }^{65}$.

Cytaty biblijne zostały podane zasadniczo według tzw. Biblii Poznańskiej (BP) ${ }^{66}$. Tam, gdzie użyłem Biblii Tysiąclecia, zostało to zaznaczone $(B T)^{67}$. Liczby w nawiasach kwadratowych oznaczają numery stron z wydania Dź. Daniczicia.

${ }^{60}$ Stefan Nemanicz, Żywot św. Symeona, wyd.: J. P. Šafařík, s. 23, wyd.: В. Велинова, s. 86; Domentijan, Żywot św. Sawy, s. 206.

${ }^{61}$ Zwrócił na to uwagę już Petyr Mutafcziew (Владетелите на Просек, s. 93), ale widział on w okrucieństwie Streza echa rzeczywistej rozprawy z Serbami, sprawującymi kontrolę nad Strezem w imieniu Stefana Nemanicza.

62 Por. przypis 55.

${ }^{63}$ W 1973 r. wydanie Dź. Daniczicia zostało przedrukowane z przedmową Dź. Trifunowicia (Теодосије Хиландарац, Живот светога Саве. Издање Буре Даничића приредио и предговор написао Ђ. Трифуновић, Београд 1973).

64 Р. Станкова, Сръбската книжнина, s. 178.

${ }^{65}$ Dar Stowa. Ze starej literatury serbskiej, red. A. Naumow, Łódź 1983, s. 41-50.

${ }^{66}$ Biblia. Pismo Święte Starego i Nowego Testamentu w przektadzie z języków oryginalnych ze wstępami i komentarzami, red. M. Peter, M. Wolniewicz, t. 1-4, Warszawa 2009.

67 Pismo Święte Starego i Nowego Testamentu w przekładzie z języków oryginalnych, red. A. Jankowski, Poznań - Warszawa 1999. 
Teodozjusz Chilandarski, Żywot św. Sawy

\section{[101] O NAGŁEJ ŚMIERCI STREZA}

Opowiadając o licznych cudach świętego, chcę wspomnieć także o zabójstwie, jakiego dokonał modlitwą. Boję się, żeby ktoś nie pomyślał, że spotwarzam go mianem zabójcy, gdyż nie ma w tym ani jego skazy, ani mojej, który to opowiadam, hańby. Jeśliby tak było, to Eliasz, Elizeusz i Mojżesz, który żył przed nimi, nie byliby godni pochwały z powodu [dokonanych] zabójstw. Pierwszy z nich spalił dwóch pięćdziesiątników wraz z [ich] ludźmi ogniem zesłanym z nieba za sprawą modlitwy ${ }^{68}$, a trzystu przeciwnych Bogu, fałszywych proroków, sam zabił nożem i [swoim] słowem zamknął przed nimi niebiosa ${ }^{69}$. Wielu ludzi zamorzył głodem, wiedziony gorliwością wszechmogącego Pana ${ }^{70}$. Drugi zaś, kiedy dzieci pogańskie naśmiewały się z niego, rozkazał niedźwiedziowi przybyć z pustyni i udusić je wszystkie, aby ich rodzice, [102] widząc to, przestraszyli się i nie byli przeciwni jego pobożnej nauce o Bogu ${ }^{71}$. Mojżesz natomiast utopił w morzu faraona ${ }^{72}$, a Amalekitów wybił, pokonawszy ich wyciagniętymi rękoma - [czyli] modlitwą ${ }^{73}$. Pomińmy wielu świętych dawniejszych i nowszych, którzy modlitwą zabijali przeciwników, abyśmy uchronili się od zbyt długiego opowiadania o tym, co było w przeszłości.

Boże było wszystko, co czynili święci. Bez Boga nic się nie dzieje, ani żadne słowo nie pada. Beze mnie - powiedzial - nic nie możecie uczynićr ${ }^{4}$. Wszystko, co za sprawą Boga czynią święci, jest mu miłe i przyjemne, nawet jeśli komuś opacznie rozumującemu wyda się złe. Bywa, że Bóg przyciąga nas ku sobie, innym razem straszy nas chorobą. I jeśli nie zbliżamy się do Niego, to [okiełznawszy] wędzidłem pyski naszych serc, strachem je dla siebie zdobywa ${ }^{75}$. A nieraz karci On nas za nasze grzechy, za zatwardziałość w złości, za to, że odwracamy się od Niego. Niezliczone sq kary dla grzeszników, ale kto Jahwe zaufat, tego łaska otacza ${ }^{76}$. Czasem też Bóg mści świętych, swoje wybrane sługi - gdy ktoś im uraga, obraża ich, lub niesprawiedliwie krzywdzi tych, którzy uciekają się do nich i szukają ich [opieki]. [Czyni to], abyśmy my wszyscy zawstydzili się, poczuli strach i nie sprzeciwiali się ich nauczaniu o Nim oraz nie lekceważyli ich dobrych rad, jak to uczynił ów głupiec, o którym będę mówić. Nie zechciał on przyjąć dobrych rad świętego i sam dla siebie przygotował kielich [103] gniewu Pańskiego.

Niejaki Strez, choć dobrze urodzony, był jednak nierozumny. Pochodził z bułgarskiego rodu carskiego, był krewnym cara zagorskiego Kałojana, którego, jak powia-

\footnotetext{
68 Por. 2 Krl 1, 9.

69 Por. 1 Krl 18, 40.

70 Por. 1 Krl 17-18.

71 Por. 2 Krl 2, 23-24.

72 Por. Wy 14, 27-28.

73 Por. Wy 17, 9-13.

$74 \mathrm{~J} 15,5$.

75 Por. Ps 32, 9.

76 Ps 32, 10.
} 
dają, zabił św. Demetriusz. Tenże Kałojan, car zagorski, wyruszył na wojnę i zburzył wiele miast greckich w całej Tracji i Macedonii, w czasach, gdy Frankowie panowali i mieli w posiadaniu miasto Konstantyna. Nie martwili się oni z powodu zniszczenia tamtych miast, gdyż nie uważali ich za swoje. Kałojan - widząc je opuszczone i bezbronne - burzył. A wszystko, co się działo, pochodziło od Boga. [Kałojan] wyruszył z wielkim wojskiem, jak dawniej Sennacheryb ${ }^{77}$, na Boże miasto, na słynne z prawowierności na krańcach ziemi, chronione przez Boga, wielkie miasto Tesalonikę, ojczyznę świętego wielkomęczennika i cierpiętnika Demetriusza. Spoczywają tam jego czcigodne relikwie, z których wypływa święty olejek. Kałojana nie zawstydziła świętość świętego, ani jego cuda. Skoro zwątpił, że olejek wypływa przy świętym grobie Demetriusza, postanowił zburzyć i spustoszyć doszczętnie Tesalonikę oraz pozostałe miasta. Lecz, za sprawą żarliwego wstawiennictwa świętego u Boga, pełen pychy [Kałojan] nie zrealizował swojego planu, nie wyciagnął strzały z kołczanu, ani nie obnażył miecza ${ }^{78}$. Kiedy przybył pod miasto, z Bożego wyroku otrzymał śmiercionośny cios w serce i nagle zmarł. W ten oto sposób, dzięki modlitwom świętego, Bóg ocalił Tesalonikę od wszelkiej szkody. Wojska, które [tam] przybyły ogarnął strach, [żołnierze] bojąc się świętego [Demetriusza] postanowili uciekać. [104] Najwyżsi dowódcy nie chcieli zostawić swojego cara mieszczanom na pohańbienie, ani zwierzętom i ptakom na pożarcie, byli mu bowiem bardzo oddani. Po raz ostatni okazali mu miłość wzięli ze sobą martwego cara, a bojąc się długiej drogi, rozcięli jego brzuch, wyjęli wszystkie wnętrzności, zasolili ciało i [tak] donieśli do swojego kraju ${ }^{79}$.

Strez, o którym już wspominaliśmy, był prześladowany i miał zostać zabity przez cara Boriła, który objął władzę po śmierci cara Kałojana, jako carski krewny. Ów Got, zwany Strezem, słynął ze swojego wyjątkowego męstwa, dlatego też zazdroszczono mu i pożądano śmierci jego duszy. [Zwolennicy Boriła] bali się, aby ich nie zabił, gdy ogłosi się carem, dlatego też nastawali na niego i wygnali go. Strez, nie mając gdzie się schronić, przybył do pobożnego wielkiego żupana i autokratora Stefana. Ten zaś miłośnik Chrystusa przyjął go radośnie ze wszystkimi, którzy z nim przyszli. Okazał mu wielką przyjaźn i wspaniałomyślność swojej pokory. Przyjął go nie jak zbiega, ale jak umiłowanego syna. Zaszczycił niegodnego miejscem przy swoim stole, tak, że liczni spośród dowódców Stefana zaczęli narzekać z powodu przyjaźni, jaką [obdarzył] Streza. Ci zaś, którzy objęli władzę w Zagorze, prosili usilnie autokratora Stefana, aby [Strez] nie pozostał przy życiu, lecz by go zabito. Czasem posyłali oni bogate dary, odwołując się do [wzajemnej] przyjaźni, a czasem grozili mu wojną, ale na próżno. Gdy Strez dowiedział się o tym, ogarnął go strach i drżenie, i rozważał czy nie uciec gdzie indziej, [105] aby nie być wydanym w ręce swoich wrogów. Pobożny Stefan upewnił go przysięgami, [że go nie wyda], aby się nie lękał. Dla utwierdzenia

77 Por. 2 Krl 18,13nn; 2 Krn 32, 1nn; Iz 36, 1nn.

78 Por. 2 Krl 19, 32.

${ }^{79}$ Grób Kałojana znajduje się najprawdopodobniej w cerkwi Czterdziestu Męczenników w Wielkim Tyrnowie, por. И. Божилов, Фамилята на Асеневци, s. 56-57. 
prawdziwej wiary i przyjaźni zaszczycił niegodnego, [czyniąc] go swoim bratem według świętej Ewangelii.

[Stefan] obdarzył Streza wieloma końmi, ludźmi i wszystkim, co mu było potrzebne. Przedtem bowiem Goci wzrośli w siłę i objęli w posiadanie wiele, jak już powiedzieliśmy, opustoszałych i pozostawionych bez żadnej pomocy miast greckich, przybyli i zajęli [również] okolice Tesaloniki i Ochrydę. Pobożny Stefan przywołał ku Strezowi, jako ku krewnemu carskiemu i swojemu bratu, pewnych władców zagorskich, którzy wówczas posiadali tamte miasta, a oni przyłączyli się do niego ze swoimi włościami. Najpierw Stefan wprowadził Streza do ufortyfikowanego miasta nazwanego Prosek, dał mu do pomocy swoje wojsko i sam mu pomógł. Umocnił go i uczynił władca, zaszczycił będąc jego towarzyszem i bratem. Obaj obiecali przychodzić sobie z wszelką pomoca. Strez objął w posiadanie kolejne miasta i wzrosła liczba jego ludzi, ponieważ mieszkańcy Zagory znali go i wielu z nich przychodziło do niego.

Chcę teraz opowiedzieć o głupocie Streza, nawet jeślibym mał przedłużyć opowieść. Bardzo się wzbogacił, można by o nim powiedzieć: „utył, zgłupiał, zapomniał Boga i chełpił się rozsądkiem"80. Okazał się zabójcą, człowiekiem niemiłosiernym, ostrym, porywczym i niezmiernie bezbożnym. Zbudował sobie we wspomnianym Proseku dom na skale [106], która jest bardzo wysoka - na 200 sążni lub więcej, a w dole opływa ją wielka rzeka zwana Wardarem ${ }^{81}$. Wyłożywszy skałę drewnem, uczynił z niej swoją scenę. Gdy nędznik był w dobrym nastroju, upiwszy się, przesiadywał na tym obmierzłym i śmiertelnym trybunale, bawił się i weselił. Jego radość była śmiercią dla ludzi. Za małe przewinienie skazywał na śmierć i rozkazywał zrzucać winowajców z tej sceny, ze skały o ogromnej wysokości. Gdy kogoś zrzucano, cieszył się i krzyczał do skazańca: „Uważaj, żebyś sobie płaszcza nie zamoczył!”, a nie mógł on upaść nigdzie indziej jak tylko do rzeki. Bliscy, jeśli zrzucony ich miał, lub ludzie bojący się Boga chodzili wzdłuż rzeki, szukając czy woda nie wyrzuciła gdzieś [ciała], aby wziąwszy je, zaszczycić ludzkim pogrzebem. Jeśli zaś [ciało] pozostało w głębinach, stawało się pokarmem dla ryb. Dlatego właśnie, jak już powiedzieliśmy, jego radość była śmiercią dla ludzi.

Takie rzeczy działy się u niego, bowiem zatwardziały pokładał ufność w sobie, w swojej twierdzy i warowni [położonej] wysoko na skale, a nie w Bogu. Mówił: „Któż [może] mnie stąd strącić?” Nędznik nie pamiętał słów: „Będziesz w największej pogardzie! Zwodzi cię pycha twego serca: mieszkasz w grotach skalnych, na wysokościach wznosisz swe mieszkanie i mówisz sobie: «Któż zdoła mnie ściagnać na ziemię?» Choćbyś się wznióst wysoko jak orzet i między gwiazdami założyt swe gniazdo, [107] stracę cię stamtad - mówi Pan." $"{ }^{\prime 2}$

${ }^{80}$ Por. Pwt 31,15. 20.

${ }^{81} \mathrm{~W}$ okolicach Proseku wzgórza położone wzdłuż rzeki wznoszą się do $220 \mathrm{~m}$ nad lustro wody. И. Микулчиќ, Средновековни градови и тврдини во Македонија, Скопје 1996, s. 230-231.

${ }^{82}$ Abd 1, 2-4. 
Pobożny Stefan smucił się, słysząc o postępowaniu Streza. Bał się Boga i obwiniał się w [swoim] sumieniu, że takiego młodzieńca - okrutnika wybawił od śmierci, dał mu schronienie i uczynił władcą. Z odrazą myślał o tym, że nazwał go swoim bratem, wielokrotnie też pisał do niego, prosząc go i upominając, aby odmienił swoje postępowanie. Lecz jak powiada Salomon: „Strofuj mądrego, a pokocha cię, głupiego, a znienawidzi cię"83, tak samo i Strez, prawdziwie bezrozumny, znienawidził tego, który go umiłował. Zapomniał o wszystkim, co niegdyś [otrzymał] od Stefana i nie okazał wdzięczności za łaskawość. Podeptawszy przykazania Boże, stał się krzywoprzysięzca, zlekceważywszy ewangeliczne braterstwo, porzucił przyjaźn Stefana i odstapił od wiary ${ }^{84}$. Stał się sługą nieprawości, skaził swoją duszę brakiem bojaźni Bożej. Za wielką łaskawość Stefana ku niemu, bezrozumny, umyślił odpłacić bezkresnym złem. Pojednał się z Grekami i połączył ze swoimi Gotami - zebrał z obu [narodów] niezliczone mnóstwo ludzi i zuchwale, jak lew ryczący ${ }^{85}$, ruszył z wojskiem na dziedzictwo [autokratora], aby niszczyć i pustoszyć.

Usłyszawszy o tym, pobożny Stefan zaczął wysyłać do tego złoczyńcy swoich dostojników, przypominając mu o dawnej przyjaźni i prosząc go, aby odmienił swoje okrutne postępowanie. Ten zaś, zatwardziały, upodobnił swoje serce do skały, tak, że upomnienia były dla niego jak wiatr. [108] Stefan, zdawszy sobie sprawę, że nie ugnie się kark tamtego z powodu jego żelaznej głupoty oraz, że prowadzi on ze sobą mnóstwo ludzi, w wielkiej rozterce odprawił wszystkich, którzy mu chcieli pomóc ludzkimi sposobami i uciekł się do Boga: „Boże, wejrzyj na mnie w nieszczęściu! Panie, pospiesz mi z pomocą! Nie zostawiaj mnie na pośmiewisko mojemu wrogowi! ${ }^{86} \mathrm{Za}$ wstawiennictwem przeczystej Twojej Matki, zawsze dziewicy Maryi i świętego ojca naszego, Twego sługi Symeona, dzięki któremu nauczyłeś nas, jak znajdować Ciebie, prawdziwe życie, za jego wstawiennictwem spojrzyj na mnie grzesznego, który pokładam nadzieję w Tobie. Rozsądź sprawiedliwie moją sprawę, bo oto odpłacono mi za dobro złem i nienawiściq za moja mitośc ${ }^{87}$, ten, który jadt mój chleb podnióst na mnie piętę ${ }^{88}$ i chce na mnie napaść, i powalić mnie. Pomóż mi Panie, mój Boże! Wybaw mnie według miłosierdzia Twego, niech się objawi bezgranicznie silna ręka Twoja i ukorzy tych, którzy na mnie powstaja, niech ujrzy mój wróg swoją hańbę i niech się zawstydzi. Niech położy rękę na swoich ustach, zadziwi się i przerazi, od strachu niech ogłuchną jego uszy! Ja, Twój sługa, będę się radował i weselił ze względu na Twoje miłosierdzie, bo wejrzałeś na moje uniżenie i wybawiłeś od czyhających na moją duszę". I zaraz zaczął razem ze swoim, danym od Boga wojskiem, przygoto-

\footnotetext{
${ }^{83}$ Por. Prz 9, 8 .

84 Wyrażenia „odstąpił od wiary” nie należy rozumieć jako „popadł w herezję”, odnosi się ono raczej do „zapomnienia o Bogu” i bezbożności, które autor zarzucał Strezowi (por. wyżej).

${ }^{85}$ Por. 1 P 5, 8.

${ }^{86}$ Wezwania modlitewne są stylizowane na fragmenty psalmów, por. np.: Ps $35,24-26$, Ps $72,12-$ -15 , Ps 109, 26-27.

87 Ps 109,5 .

${ }^{88}$ Ps 41,9 (wg BT).
} 
wywać się gorliwie do wyruszenia przeciwko wrogowi. Osłonił się ufnością pochodzącą z modlitwy jak zbroją.

Przepełniony Bożą mądrością archimandryta Sawa stanął przed wszystkimi jak [109] Mojżesz i drugi Samuel, bowiem w sercu współczuł nieszczęściu brata, a duszą cierpiał z powodu swojej ojczyzny i martwił się o swój lud. Wiedział, że nie jest możliwe, aby w wielkiej bitwie wielu nie poniosło śmierci, szczególnie zaś spośród tych najbardziej wiernych i żarliwych w boju. Zatrzymał więc autokratora oraz jego wodzów, mówiąc: „Ja pierwszy pójdę do przeciwnika i przemówię do niego, jeśli mnie pouczającego o Bogu nie posłucha, tak jak [nie posłuchał już] innych, wówczas wy zaczynajcie po ludzku". I wyruszył z pokorą i wiarą Dawida ku owemu Goliatowi, i zobaczył zebrane ogromne mnóstwo ludzi, idących na jego kraj, wśród nich swego towarzysza [Streza, jak o nim] Dawid mówi: „Widziatem, jak występny się pysznit i rozpierat się jak cedr libański" "89.

Kiedy [Strez] zobaczył świętego, pokłonił się, padłszy na ziemię, tak jak miał w zwyczaju jeszcze u autokratora Stefana. Święty, przyjęty życzliwie, pocałował go. Po powitaniu zasiedli przy stole. Sawa upomniał Streza w obecności wielu wiernych licznymi słodkimi i Bożymi słowami, aby porzucił zapalczywość swojej lekkomyślności i żył z nim jak dawniej, w przyjaźni; aby nie stał się przyczyną przelewu krwi i śmierci wielu ludzi. [110] Wszyscy, którzy to słyszeli, dziwili się słodyczy mowy i sile słów świętego, mówili najmądrzejszemu: „Przyjemne słowa sa plastrem mio$d u$, stodycza dla duszy, lekiem dla kości" ${ }^{\prime 0}$, Strez zaś wydawał się srogi i nie słodki, lecz gorzki. Wszyscy zdumiewali się świętym i zwracali się do niego z prośbami, a na Streza oburzali się. Gdy powstali od stołu, święty znów zaczął mówić do tamtego na osobności, przekonując i prosząc go, aby powrócił do wielkiej przyjaźni, która panowała między nimi wcześniej. Przypominał mu przyjazne przyjęcie i wybawienie od tych, którzy pragnęli śmierci jego duszy, opiekę [jaką go obdarzono] i pobratymstwo. Pouczył go, aby nie zlekceważył bojaźni Bożej, ani nie śmiał igrać z Bogiem, łamiąc przysięgę. Opowiedział mu też o lecącym sierpie z wizji Zachariasza ${ }^{91}$, długości dwudziestu, a szerokości dziesięciu łokci, którym żnie się krzywoprzysięzcę, nie wykazującego skruchy aż do śmierci. Niemożliwe jest powtórzyć wszystko, co swymi głoszącymi Boga ustami wypowiedział [Sawa], pouczając i przywołując do rozsądku. Pragnąc życia dla Streza, wyciągał jego duszę z przepaści śmierci. Ów zaś twardego serca i głuchy nieuwaga, zatkał uszy jak żmija, [która nie chce słyszeć] zaklinacza ${ }^{92}$. Gdyby [tylko] usłyszał głos świętego! [Strez jednak] zupełnie zlekceważył słowa słodkie i wspaniałe, budzące bojaźń i grozę, wypowiedziane prorockimi i pięknomówiącymi ustami, w niczym nie był im posłuszny. Prepodobny ${ }^{93}$ widząc jego za-

\footnotetext{
${ }^{89}$ Ps 37, 35 (BT). W tekście BT „zielony” w miejsce „libański”.

${ }^{90}$ Prz 16, 24 (BT).

91 Zach 5, 1-4. W BP i BT: „lecący zwój”.

92 Por. Ps $58,5$.

93 Prepodobny - „nazwa określająca rodzaj świętości oraz oznaczająca człowieka, który trwając w dziewictwie, w odosobnieniu od doczesnego świata, prowadząc surowe życie zakonne, osiągnął świętość" - A. Znosko, Stownik cerkiewnostowiańsko-polski, Białystok 1996, s. 262-263.
} 
głuszone sumienie, nieskruszoną wolę, nieustępliwe usposobienie i zatwardziałość, powiedział do niego: „Mówiliśmy to chcąc dobra naszego i waszego. Ponieważ jednak położyłeś nadzieję w orężu i nie posłuchałeś mnie, gdy ci radziłem dobrze, to sam na siebie zło sprowadziłeś. Wiedz, że my, którzy zawierzyliśmy Bogu, nie przestraszymy się was, ani nie [111] wycofamy się [z powodu] liczebności waszych [wojsk]. Konia należy uzbroić na dzień bitwy, ale zwycięstwo zależy od Jahwe $e^{94}$. Bóg niech nas rozsądzi!" Tak go pożegnał i wyszedł, był bowiem już wieczór.

Prepodobny wszedł do swojego namiotu i wzniósł ręce do Boga. Modląc się z głębi duszy i prosząc o pomoc mówił: „Bądź nam pomocą, o Panie, bo innego pomocnika w utrapieniach prócz Ciebie nie mamy. Panie zastępów, sędzio sprawiedliwy, który badasz serce i wnętrzności, Tobie powierzam moja sprawę ${ }^{95}$. Ty wiesz, że nie przyłożyliśmy ręki do tego zła, pozwól mi zobaczyć karę [zesłana] od Ciebie na tego, który niesłusznie zaufał swej sile i zaostrzył swój miecz na nas. Wprowadź swą moc w jego serce, Panie zastępów. Sędzio sprawiedliwy, Tobie ufam: niech nie doznam zawodu! ${ }^{96 "}$ Tak modlił się ze łzami, prosząc o pomoc. Przyzywał przeczystą Bogurodzicę, aby go wysłuchała w potrzebie. Do świętego ojca swego, prepodobnego Symeona, widząc go naocznie, mówił: „Ojcze, bezbożnicy nastają na twoje dziedzictwo. Nie przemilczaj naszej sprawy w swoich modlitwach do Chrystusa, nie wydawaj na pohańbienie dzieci i sług twoich!" Natychmiast został pokrzepiony w duszy słowami Ducha Świętego: „Ja jestem Pan, twój Zbawca” "97 i bezzwłocznie, [jeszcze tej] nocy, udał się w drogę powrotną. Ten, który nie przyjął świętego, radzącego mu dobrze, śpiąc spokojnie w [swoim] łożu, niespodziewanie zaczął krzyczeć strasznym głosem. Miłe są Panu prośby sprawiedliwego ${ }^{98}$, Bóg wysłuchuje modlitw tego, który się Go boi! Posłał bowiem nieprzebłagalnego anioła, [112] który przeszył środek zatwardziałego serca Streza. Ów zaś, pełen żalu i ledwo dysząc, powiedział tym, którzy przestraszeni pytali go o przyczynę krzyku: „Jakiś przerażający młodzieniec, z rozkazu Sawy, napadł mnie gdy spałem i chwyciwszy mój miecz, przebił mi wnętrzności”. Natychmiast zaczął prosić uniżenie wszystkich, aby odszukali wielkiego Sawę. Oni wybiegli, ale nie znaleźli świętego, gdyż już odszedł. Tak zasądził Bóg, aby nie znaleziono tego, który mógł wybawić Streza. Nocą z powodu niewidzialnej rany w sercu nieoczekiwanie oddał on ducha z wielkim jękiem. Żołnierzy zgromadzonych przez niego objął wielki strach, ponieważ widzieli nagłe zabójstwo dokonane modlitwą świętego. Bojąc się napaści Stefana, szybko zaczęli wracać, [każdy] do siebie.

Niektórzy spośród możnych, to jest sług Streza, chcieli przyłączyć się do wojsk Stefana. Oni to dogoniwszy świętego, opowiedzieli mu o niespodziewanym i niewidzialnym zabójstwie. Święty zaś płakał donośnym płaczem z powodu zatwardziałości Streza i dziękując Bogu, wrócił do Stefana. [Bracia] utwierdzili się w przyjaź-

\footnotetext{
94 Prz 21, 31.

95 Iz 11, 20 (BT).

96 Ps 25, 2.

$97 \mathrm{Iz} 49,26$.

98 Por. Prz 15, 29.
} 
ni i pokoju. Święty nie śmiał pochwalić się tym, co zaszło, ani opowiedzieć o tym. Ze strapienia był smutny i przygnębiony. Stefan dowiedział się przyczyny tej zgryzoty od tych, którzy byli ze świętym. Nie miał śmiałości, aby go wypytywać o to, dowiedział się jednak u żołnierzy o wszystkim i usłyszał o strasznej śmierci przeciwnika. [113] Ogarnięty strachem dziwił się temu i wysławiał Wszechmogącego za to, co się stało. Wiele też łez przelał nad Strezem, [ponieważ] miłował go jako brata według Ewangelii i jako tego, którego wielokrotnie gościł przy stole. Obdarzony Boską mądrością Sawa przyzwał do swego brata, autokratora, wszystkich wyższych dowódców i tak pouczył ich i swojego brata Bożymi słowami: „To Pan, Bóg, za sprawą modlitw przeczystej jego Matki i jego sługi, świętego i prepodobnego Symeona okazał wam pomoc. Bez siły konia i męstwa człowieka, bez jakiejkolwiek broni, jak widzicie, zabił waszego wroga. Stało się tak przez nieugiętą wolę Streza, jego hardy kark, brak miłosierdzia względem ludzi stworzonych jak i on sam [przez Boga], niedochowywanie przysięgi, lekceważenie bojaźni Bożej. Żadne zło nie może uniknąć sądu Bożego i gniewu! Mściwość Pańska nie spocznie, ścigając łamiących prawo Boże, dopóki ich nie dosięgnie. Gdy [Bóg] odkłada na później swój gniew i znosi grzeszników, to [tylko dlatego, że] czeka na ich nawrócenie. Jeśli oni nieskruszeni [skłaniają się] ku złu i odwracają się od Niego, wówczas szykuje im jeszcze cięższą kaźń. I kiedy [grzesznicy] myślą, że już uciekli przed sądem Bożym, wówczas spada na nich niespodziewana kara, tak jak na tego, o którym słyszycie, że za sprawą Boskiego wyroku poniósł straszną śmierć. Wy jednak nie bądźcie nierozumni, ani pozbawieni strachu. Przyozdóbcie swoje życie bojaźnią i drżeniem, nie stawajcie do niesprawiedliwej wojny! Pamiętajcie, [114] że Bóg jest zawsze z nami, i czy robimy coś dobrego czy złego, wszystko przed Nim jest jasne i bez osłony, żaden z naszych wstydliwych czy tajnych postępków nie ukryje się przed Jego wszystkowidzącymi oczami. Jeśli w Nim pokładamy nadzieję i Jemu służymy, nasi wrogowie nie mogą nam wyrządzić żadnego zła. Pan jest twojq ucieczka, za obrońce wziałeś sobie Najwyższego. Niedola nie przystapi do ciebie, a plaga się nie przybliży do twego namiotu99. Tak i wy pokutujcie za wszystkie [złe postępki], dziękujcie Wszechmocnemu i głoście razem z Dawidem: On o nas pamiętał w naszym uniżeniu, i uwolnit nas od wrogó $w^{100}$. Nie pokładajcie nadziei w łuku, ani ramieniu, ale w Panu ${ }^{101}$ czyniącym niezliczone wielkie i niepojęte, wspaniałe i cudowne dzieła. Rozejdźcie się do siebie w pokoju, nie podjąwszy walki, obronieni przez Boga. Bądźcie zdrowi!”

Pobożny autokrator Stefan i wszyscy dostojnicy, przejęci strachem przed Bożą siłą, pozostali w milczeniu po wysłuchaniu tej straszliwej katechezy świętego. Wszyscy kłaniali się Bogu, dziękując za okazaną im pomoc i za cudowne zwycięstwo bez walki. Chwaląc Boga i zdumiewając się świętością Sawy, radośnie rozeszli się, każdy w swoją stronę.

\footnotetext{
99 Ps 91, 9-10.

100 Ps 136, 23-24.

101 Por. Ps 44, 7-8.
} 


\title{
"LIFE OF ST. SAVA" BY THEODOSIUS OF CHILANDAR AS A HISTORICAL SOURCE ON STREZ, THE RULER OF PROSEK
}

\begin{abstract}
Summary
The late XII and the early XIII c. were a period of important political changes on the Balkan Peninsula. Strez (1207-1214) was one of the local rulers which emerged in the mountain regions of the central Balkans in that time. We know the outline of his life from the sources such as: "Life of St. Symeon" by Stefan the First-Crowned, "Life of St. Sava" by Domentijan, "Life of St. Sava" by Theodosius of Chilandar and the letter of the Latin Emperor Henry from the January of 1212 or 1213 . The paper presented here is divided into two parts. In the first part the Author presents the sources mentioned above and discusses major problems concerning their interpretation: the chronology of Strez's life, territorial extent of his state, relations with the neighbor countries and circumstances surrounding his death. The second part comprises translation of the excerpt about Strez from the "Life of St. Sava" by Theodosius of Chilandar.
\end{abstract}


